Contemporary Research in Education and English Language Teaching

ISSN: 2641-0230

Vol. 2, No. 1, pp. 1-15

2020

Publisher: Learning Gate

DOI: $10.33094 / 26410230.2020 .21 .1 .15$

(C) 2020 by the authors; licensee Learning Gate

\title{
Fijian Women - Key Providers to Sustainable Development Goals (A Case Study of the University of Fiji)
}

\author{
Manpreet Kaur \\ Academic and Professional Qualifications: Master of Arts in English - The University of Fiji, Fiji. \\ Email: manpreetk@unifiji.ac.fj \\ Sanjaleen Prasad \\ Academic and Professional Qualifications: Master of Arts in English - The University of Fiji, Fiji. \\ Email:sanjaleenp@unifiji.ac.fi
}

Received: 19 August 2020; Revised: 21 September 2020; Accepted: 13 October 2020; Published: 28 October 2020

\begin{abstract}
Fijian women continue to engage in decisive roles in the fields of economic and social development of Fijian society through paid employment services in the various sectors of the economy. In light of the Millennium Development Goals (MDG) and Fiji's commitment to Sustainable Development Goals (SDG), striving a balance in the three pillars of SDG namely economic, environment and social is fundamental in achieving sustainability and overall growth of the country. However, with the growing concerns of gender equality across the globe, it is imperative than ever to sustain the growth of Fijian women through education, capacity building, improved healthcare, equal job opportunities and women participation and representation at national levels for decision making processes. Hence, this paper aims to investigate the various roles played by women workforce at The University of Fiji and their contributions towards sustainable development of women. The paper further examines the prospects of development and growth as well as challenges impeding Fijian women at The University of Fiji in realizing their potential to effectively and intensely contribute towards the growth of the country. The paper will plausibly explore resolutions to equip Fijian women workforce at The University of Fiji in order to effectively contribute towards the sustainable development and growth of Fiji.
\end{abstract}

Keywords: Fijian women, Millennium development goals, Sustainable development, Knowledge, Gender, Education.

\section{Introduction}

Women play a fundamental role in all spheres of life be it home, community building, rearing the children, health care of the family, to supplementing family income, to effectively contributing towards nation building through decision making process. However, women across the globe are constantly challenged with myriad issues impeding their potential to grow. The United Nations formulated Millennium Development Goals (MDG) with eight goals that UN Member States agreed upon in order to achieve measurable improvements in critical areas of human growth by 2015 (World Health Organization, 2017). In September 2000, World Leaders signed The United Nations Millennium Declaration, committing to eradicate poverty, famine, environmental degradation, illiteracy, disease, and discrimination against women. On 25 September, 2015, The United Nations General Assembly adopted the 2030 Agenda for Sustainable Development with 17 goals viewed to be translated into tangible progress, superseding the MDG. 17 Sustainable Development Goals and 169 targets are built on the premise of the MDGs with a far broader and deeper capacity. The purpose of SDGs is to construct a set of pertinent aims that stabilizes the three key constituents of sustainable development: environmental, 
social, and economic, in order to bridge the gap between the rhetoric and the global reality at hand. Thus, women have a decisive role in all the SDGs with objectives particularly acquainting women's equality and empowerment as both the intent, and as an element of resolution.

On the onset, presently it is exigent to empower women across the globe. According to European Parliament (2016b) empowerment is characterized as a "multi-dimensional social process that assists people gain control over their lives. It is a process that fosters power (that is, the capacity to implement) in people, for use in their own lives, their communities, and in their society, by acting on issues that they define as important." To achieve a desire outcome in terms of productivity, it is critical for women to be empowered, in order to successfully contribute towards the growth of different economic, socio-cultural and political spheres. Once females realize their potential, more so if in labour force, this can act as a stepping stone in their quest to achieving gender equality, which is understood to mean that the "rights, responsibilities and opportunities of individuals will not depend on whether they are born male or female" (2016:8). According to the UN Population Fund, an empowered woman has a sense of selfworth. She can determine her own choices, and has access to opportunities and resources providing her with an array of options she can pursue. She has control over her own life, both within and outside the home and she has the ability to influence the direction of social change, thus creating social and economic order, both nationally and internationally.

According to findings by Economic Empowerment of Women, UN Women Publications (2013) the benefits of economic empowerment clearly states that "when more women work, economies grow, if women's paid employment rates were raised to the same level as men's, the USA gross domestic product would be approximately 9 percent higher, the Euro zone's would climb by 13 percent, and Japan's would be boosted by 16 percent". Also, in 15 major developing economies, per capita income would rise by 14 percent by 2020, and by 20 percent by 2030. Empirical evidence from a range of countries show that increasing the share of household income controlled by women, either through their own earnings or cash transfers, changes spending in ways that benefit children. More so, when women entail in paid labour across the globe, in majority of the countries, women's wages represent between 70 percent and 90 percent of men's, with even lower ratios in some Asian and Latin American countries. If women had the same access as men to productive assets, agricultural output in 34 developing countries would rise by an estimated average of up to 4 percent. This could reduce the number of undernourished people in those countries by 17 percent, translating to up to 150 million fewer hungry people (UN Women Publications, 2013).

In 'Progress of the World's Women: Transforming Economies, Realizing Rights' (UN Women, 2015). The Secretary General of the United Nations, Ban Ki-Moon stressed the urgency to necessitate the vitality of women's economic and social rights in order to construct strong and pliant economies and societies. It further exemplifies that governments and international community that have fallen short in comprehending the full inclusion and participation of women and girls, continue to struggle as an economy. It illustrates how and where immediate action can redress this critical imbalance. The report's findings and recommendations underline the need to respect and promote the specific rights and needs of women and girls, and to integrate gender equality in all dimensions of sustainable development.

The University of Fiji has a five year (2017-2021) Strategic Plan - the Global Path to Academic Excellence and building a knowledge-based society, aimed at advancing global recognition for academic excellence in the construction and dissemination of new knowledge. According to the Vice- Chancellor of The University of Fiji, Professor Prem Misir, the eight strategic themes such as Learning and Teaching; Student Services; Environmental and Social Responsibility; Infrastructure and Systems, Governance and Financial Sustainability; Risk Management and the Accountability Framework are entrenched within the knowledge-based development framework, geared towards contributing to the growth of the knowledge society in Fiji. The common denominators of the strategic goals can be fully be achieved if women are entailed in decision making, research, appraisals, managerial positions and other key areas whereby they realize their potential and contribute significantly. 


\section{Background of the Study}

The research concentrates on Fijian women workforce at The University of Fiji, a locally owned tertiary institution based in Saweni, Lautoka, Fiji. The institution was established in December 2004 and is now in its 12 year of operation. The research is focusing on the two campuses that the University presently has: Saweni, Lautoka and Kula Street, Samabula, Suva. The reference of Fijian women in this research denotes women working in Fiji, particularly women workforce at the chosen institution. The adoption of this common name, the proclivity of identifying all races of people, in particular nonindigenous ethnicities as Fijians is derived from the 2013 Fijian constitution that explicitly names all citizens of Fiji as Fijians rather than the previous hyphenated identities for different ethnic groups. The word is not limited to indigenous women only, but inclusion of all Fiji citizens as Fijians. However, in 2007, Fiji Labour Stats revealed 32.7 percent female labour force participation in comparison to 67.3 percent male in workforce for the same period. According to the Country Partnership Strategy: Fiji, 20142018, women far outweigh men as full-time household workers, at 115,310 compared with 1,312 in 2008. The female share of the unemployed increased from 39 percent in 2002-2003 to 43 percent in 2008-2009. Females increased their share of the economically active from 30 percent to 33 percent, with the share of wages and salary increasing by 6 percent from 29 percent to 31 percent. It further depicted that households headed by married women have a slightly lower poverty incidence than households headed by married males."

\section{Aims and Method}

Journal articles, papers and reports produced by a range of national, international and nongovernmental agencies were studied and important findings and materials in the area identified formed the premise of the research paper. Discussions and interviews conducted with female workforce who were selected using simple random sampling at The University of Fiji formed part of the findings. Semistructured interviews were useful for the conceptual development and planning of the study. The qualitative aspect has been collated through focus group discussions with selected female workforce and in-depth interviews with randomly selected female staff. One of the challenges faced during research was the lack of any research on Fijian women at The University of Fiji. In fact, there was no available work on gender focusing women at the institution level. Also, there is sparse information on women workforce at tertiary institutions in Fiji. While studies have been on women and gender in Fiji, specific focus is lacking on tertiary women workforce and their contributions towards SDGs. It is anticipated that this paper through its investigations, will generate substantial information on women's contribution towards sustainable development goals and further initiate investment in women through improved socio-economic, participatory approach and gender equality being factored in each domain at the institution.

\section{Significance of the study}

This study is of significance to Fiji in recognizing the need to empower Fijian women in workforce as they continue to assist in economic, social and environmental domains. The study will aid Fijian women in identifying the various roles they play, particularly focusing on women workforce at The University of Fiji and their contributions towards sustainable development of women. The paper is aimed at examining the prospects of development and growth for women workers at the university and major challenges impeding their growth and in realizing their potential to effectively and intensely contribute towards the growth of the county. Through an intensive study on Fijian women workforce at The University of Fiji, empirical evidence and data analysis will be made available to reasonably explore resolutions to equip Fijian women workforce in tertiary institution in order to effectively contribute towards the sustainable development and growth of Fiji. The study will further aid tertiary institutions to fully realize the diverse roles women human resources play and should there be a need to revisit and relook at policies pertaining to Women's growth, it should be addressed with urgency. 


\section{Literature Review}

\subsection{Introduction}

The $7^{\text {th }}$ of the eight Millennium Development Goals calls for environmental sustainability with a deadline set as 2015. The 189 Member States of the United Nations unanimously agreed upon this and countries have thus begun work towards achieving these goals. "Although significant achievements have recorded with respect to the MDG targets worldwide, progress has been uneven across regions and countries, leaving significant gaps. Millions of people are being left behind, especially the poorest and those disadvantaged because of their sex, age, disability, ethnicity, or geographic location".

Sustainable development means resourceful use of available resources to accommodate the current needs and wants without compromising the lives of the future generation (Kaushik, 2016; Ogato, 2013). "The SDGs are built on the Millennium Development Goals (MDGs). However, contrarily to the MDGs that were intended for action in developing countries only, the SDGs apply to all countries. They cover three dimensions of sustainable development: economic growth, social inclusion and environmental protection” (European Parliament, 2016a).

\subsection{Gender Equality and Sustainable Development}

"The three pillars of sustainable development - economic, environment and social - are also relevant to discussions of gender equality. An increasing number of studies indicate that gender inequalities are extracting high economic costs and leading to social inequities and environmental degradation around the world" (Boston University, 2010). This calls for an even greater need to consider gender issues for sustainable development.

"Sustainable human development is concerned about gender equality and women's empowerment as one dimension" (Ogato, 2013). Many nations have now begun the fight towards equality between the two genders and this is a step towards sustainable development. This is apparent in a number of global measures and arrangements such as "principle 20 of the Rio Declaration on Environment and Development, 1 adopted in 1992, the Beijing Declaration and Platform for Action, 2 adopted by Member States in 1995 and the outcome document of the United Nations Conference on Sustainable Development, entitled "The future we want", adopted in 2012" (Asian Development Bank, 2014). All these and others regard women as important partners in achieving sustainable development and integrate gender concerns and aspects into policies for sustainable development.

Gender disparity occurs in opportunities and resources, class, poverty, ethnicity, geographical location, employment, culture, home, ownership of economic assets, decision making and the list is immemorial (Ogato, 2013). Due to this, "food production and other activities that provide income and sustenance to households have been undermined” (Ogato, 2013).

"Without promoting gender equality and women's empowerment in sustainable development efforts, it is hardly possible for least developed countries ... to achieve the millennium development goals" (Ogato, 2013).

\subsection{Sustainable Development and Women}

Women play a key role in the sustainable development of any organization or nation. This needs to be realized before it is too late and humans begin to exploit the available resources relentlessly, without considering the future generation's needs and wants. The 17 sustainable development goals and 169 targets reflect and have integrated women and girls to realize everyone's human rights, to attain gender impartiality and to empower all girls and women (European Parliament, 2016b).

Women play powerful roles everyday from educating children to feeding people and they can be a vital component in any sustainable development project. "In Rio, women were considered a "major group" whose involvement in the United Nations Earth Summit held in 1992 was a necessary prerequisite for achieving sustainable development" (Kaushik, 2016).

"Women prepare up to 90 per cent of meals in households around the world, yet when times are tough, women and girls may be the first to eat less. Households headed by women may not eat enough 
simply because women earn at lower levels, and are less prepared to cope with sudden crisis" (UN Women, 2016). In order for a country to develop sustainably, women must be educated on poverty alleviation, health issues, gender inequality, inclusive platforms, education, climate change, resilient infrastructure and sustainable management of resources. "Investments in research and development will be key, but most researchers are still men - women account for only 25 per cent in more advanced Organization for Economic Co-operation and Development countries. Similarly, the construction, manufacturing and energy businesses, with few women employees and decision-makers, fall far short of gender balance. From the factory floor to the high-tech lab, women must have equal opportunities in building a shared, sustainable future" (UN Women, 2016).

"Women make up 47 per cent of the world's 120 million people working in fisheries and outnumber men in both large-scale marine fisheries (66 per cent) and small-scale inland fisheries (54 per cent). And yet, women are largely concentrated in low-skilled, low paid jobs with irregular, seasonal employment in processing, packaging and marketing. They often work without contracts or health, safety and labour rights protections. Women also earn approximately 64 per cent of men's wages for the same work in aquaculture" (UN Women, 2016). In order to ensure sustainable use of the world's oceans, seas and marine resources and to respond to vulnerabilities such as ocean degradation, women's representation in marine science needs to be corrected.

Women have an essential role to play in a transition toward sustainable energy practices in the household, as they are the main users of energy, they influence family purchases, and are educators of children. Women need to be active shareholders in the planning of policies and mitigation strategies and capacity building.

Tourism is a major contributor for the development of any nation. However, this "can also have ramifications, such as disrupting social structures, harming the socio-cultural authenticity of host communities, and threatening natural and cultural heritage" (Skanavis \& Sakellari, 2008). The population needs to be educated on this so that the effects can be minimized and eradicated. Since women are engaged in many roles both in and out of the home, their "education and access to information are critical in order to acquire knowledge, develop the necessary skills and opportunities for participation in environmental decisions" (Skanavis \& Sakellari, 2008). Prior studies indicate that women have a higher level of environmental concern and can play a huge role where safety is concerned especially at local level (Skanavis \& Sakellari, 2008). Thus, it is important that women are involved in all efforts of sustainable development.

\subsection{Sustainable Development in the Pacific}

"The PICTs cover a land area of only $553,959 \mathrm{~km} 2$ spread in the world's largest ocean. Interestingly, the ratio of sea to land area for the developing countries in the South Pacific is quite large. Kiribati, for instance, has a sea area of 3,550,000 km2, over 5,000 times its land area" (Koshy, Mataki, \& Lal, 2008).

"Traditionally, Pacific Island people have lived a subsistence lifestyle with taboos and practices that promoted sustainability of resource use. The traditional and indigenous approaches to sustainability were embodied in systems of knowledge and practice applicable to all sectors of their livelihood, such as controlled access and use of natural resources, food security (agriculture and marine) and food preservation techniques, weather and seasonal climate forecasting, traditional medicines, waste management and social relationships" (Koshy et al., 2008). This means that culture can be useful in sustainable development. "The World Bank, for example, acknowledges that prospects for economic development [in the Pacific] are conditioned to a large extent by the islands' social patterns', and that cultural endowments exert a profound influence over the pattern... of development" (Hooper, 2005).

Individual Pacific Island Countries have committed to prevent further environmental damage and to promote sustainable development. "Fiji has begun an exercise which hopes to engage as many citizens as possible in shaping its national development plan - an immediate five-year plan and a long-term 20-year development plan" (Zibiah, 2015) and gives an opportunity to all - youths, men and women alike to 
contribute in this exercise. The country takes into account the fact that "numerous studies have proven that when women are involved in development plans from conceptual phases to implementation stages, projects and communities thrive. Women bring to the table different albeit complementary perspectives to existing narratives. While men are more likely to consider capital investments, infrastructure-related issues, women are more likely to address basic everyday issues -clean water supply, health services and food security. To deny women at the consultation table, whether at a personal level or community level, is to deprive the community of substantive and holistic input with micro-level considerations" (Zibiah, 2015).

The Pacific Island Countries, however, are fighting a battle for sustainable development. "Key issues such as political stability, provision and quality of basic government services, the viability of the private sector, better and transparent governance at all levels, adaptive societies and the maintenance of cordial relationships with development partners are central to the challenges and opportunities confronting PICTs. In addition, the relationship with past and present colonizers (in the case of the territories) also has a significant influence on the present and future development directions of PICTs" (Koshy et al., 2008).

However, despite the many challenges faced by the Pacific Island Countries, measures are still put in place to ensure that communities consume the available resources sustainably.

\subsection{Synopsis}

Generally, according to a report by Organization for Economic Co-operation and Development (OECD) (2008) studies reveal that if better use were made of the world's female human capital, economic growth would increase in all countries, the number of people living in poverty would decline in all countries, fertility rates would rise in OECD countries and decline in non-OECD countries, business performance and innovation would be enhanced, the cost-effectiveness of health care and social programmes would be raised, government policies would better respond to the need of all citizens and environmental damage from unsustainable activities would decrease.

Women need to have equal access to opportunities and resources in the country, communities and families so that they can boost the standard of living in general. There is a need to strengthen women's contribution in the decision making process and most importantly, there is a need to change the unfavourable stereotypical attitudes and suppositions in regards to female participation in the various areas. Women have been the backbone of many sectors and they need to be recognized and strengthened so that nations thrive in their many sustainable development efforts.

\section{Results and Discussions}

\subsection{Staffing at the University of Fiji}

In 2017, the total number of staff at The University of Fiji's two campuses, namely Saweni and Suva is 182. The three major staff sections are Academic Staff, Management Staff and Support Staff. There are a number of staff positions within these three sections. Out of the 182 staff, 98 are female, making up a $53.8 \%$ of women in the workforce at the university. Even though the female existence in the workplace is emergent, women do not yet share in economic and political leadership. While there is a moderately equal women participation in the workforce at the university, the staffing data evidently depicts that roles and positions are generally gendered, whereby the administrative work at grounds level are mostly conducted by females. Areas that require soft skills such as clerical work, stenography, Personal Assistants and cleaning work are mostly executed by women. For instance, Administrative Assistant and Cleaners are mostly females in caparison to males. Of the 78 Support Staff that the institution has, 40 are female while 30 are males. This figure too is heavily gendered as all grounds personnels are males while, Cleaners are females. Similarly, in Management, males are holding key positions ranging from the Vice-Chancellor, to Registrar, Executive Director Finance and University Librarian. Of the 9 managerial positions, only two are females. This exemplifies the lack of female 
representation in decision making process of the university, considering the senior management of the university staff are male dominated by nature of positions.

However, while this may be due to the applications received during the filling of vacant positions and appointments thereafter are done purely on merits, it is crucial for the Screening and the Appointments Committee within the University to ensure that gender is factored in their selection criteria. Rather than just the urgency to fill in the vacant positions, the recruitment team needs to address all the aspects and if need be work on the advertisements to have more candidates given a fair chance. Also, the university needs to consider advertising its vacant positions in sources other than its current practice of heavily reliance on the leading newspapers in the country.

Table-1.

Management Positions at the University.

\begin{tabular}{l|c|c|c}
\hline Positions & No. Female Staff & No. Male Staff & Total No. \\
\hline Management & $\mathbf{2}$ & $\mathbf{7}$ & $\mathbf{9}$ \\
\hline Associate Professor & 1 & 2 & 3 \\
\hline Executive Director Finance & & 1 & 1 \\
\hline Professor & 1 & 1 & 2 \\
\hline Registrar & & 1 & 1 \\
\hline University Librarian & & 1 & 1 \\
\hline Vice-Chancellor & & 1 & 1 \\
\hline
\end{tabular}

Table-2.

Staffing positions per campuses at the university.

\begin{tabular}{c|c|c|c}
\hline & Saweni Campus & Suva Campus & Total \\
\hline Female & 84 & 14 & 98 \\
\hline Male & 76 & 8 & 84 \\
\hline Total & 160 & 22 & 182 \\
\hline
\end{tabular}

Table-3.

Staff positions and section.

\begin{tabular}{l|c|c|c}
\hline $\begin{array}{l}\text { Count of Employee Code } \\
\text { Row Labels }\end{array}$ & Female & Male & Grand Total \\
\hline Academic & $\mathbf{4 8}$ & $\mathbf{4 7}$ & $\boldsymbol{9 5}$ \\
\hline Assistant Lecturer & 9 & 8 & 17 \\
\hline Associate Professor & 1 & 3 & 4 \\
\hline Coordinator - Nursing & 1 & & 1 \\
\hline Lecturer & 19 & 5 & 9 \\
\hline P/T Assistant Lecturer & 4 & 4 & 5 \\
\hline P/T Lecturer & 1 & & 2 \\
\hline P/T Tutor & 2 & 2 & 1 \\
\hline Professor Technical & 1 & & 3 \\
\hline Project Manager & 3 & & 1 \\
\hline Quality Assurance Officer & 1 & & 12 \\
\hline Research \& & 4 & & 1 \\
Officer & 1 & & 3 \\
\hline Senior Lecturer & 1 & & \\
\hline Student Counselor & & & \\
\hline Tutor & & & \\
\hline
\end{tabular}




\begin{tabular}{|c|c|c|c|}
\hline Management & 2 & 7 & 9 \\
\hline Associate Professor & 1 & 2 & 3 \\
\hline Executive Director Finance & & 1 & 1 \\
\hline Professor & 1 & 1 & 2 \\
\hline Registrar & & 1 & 1 \\
\hline University Librarian & & 1 & 1 \\
\hline Vice-Chancellor & & 1 & 1 \\
\hline Support & 48 & 30 & 78 \\
\hline Administrative Assistant & 9 & 1 & 10 \\
\hline Administrative Officer & 1 & & 1 \\
\hline Admissions Officer & 1 & & 1 \\
\hline Assistant Registrar & & 1 & 1 \\
\hline Bookshop Staff & 2 & & 2 \\
\hline Canteen Staff & 5 & 2 & 7 \\
\hline Chef & & 1 & 1 \\
\hline Cleaner & 8 & 2 & 10 \\
\hline Electrician/Air-con Tech & & 1 & 1 \\
\hline Examination Officer & 1 & & 1 \\
\hline Finance Assistant & 2 & 1 & 3 \\
\hline Finance Officer & 1 & & 1 \\
\hline GIS Technician & & 1 & 1 \\
\hline Groundsman & & 6 & 6 \\
\hline HR Officer & 1 & & 1 \\
\hline ICT Assistant & 1 & & 1 \\
\hline IT User Assistant & & 2 & 2 \\
\hline Laboratory Technician & & 1 & 1 \\
\hline Librarian/Researcher & 1 & & 1 \\
\hline Library Assistant & 4 & 1 & 5 \\
\hline $\begin{array}{lll}\text { Manager } & \text { Finance } & \& \\
\text { Facilities } & & \end{array}$ & & 1 & 1 \\
\hline Manager HR & 1 & & 1 \\
\hline Marketing Officer & 1 & & 1 \\
\hline Media Relations Officer & 1 & & 1 \\
\hline $\begin{array}{ll}\text { Medical } & \text { Laboratory } \\
\text { Technician } & \\
\end{array}$ & 1 & 1 & \\
\hline Network Administrator & & 1 & 1 \\
\hline Nurse & 1 & & 1 \\
\hline P/T Research Assistant & & 2 & 2 \\
\hline $\mathrm{PA}$ & 1 & & 1 \\
\hline Plumber/Joiner & & 1 & 1 \\
\hline Procurement Officer & 1 & & 1 \\
\hline $\begin{array}{ll}\text { Project } & \text { Assistant } \\
\text { Technical } & \end{array}$ & 1 & & 1 \\
\hline Research Assistant & 1 & 1 & 2 \\
\hline Senior IT Support Assistant & & 1 & 1 \\
\hline Senior Library Assistant & 1 & & 1 \\
\hline Student Assistant & 1 & 1 & 2 \\
\hline Switchboard Operator & 1 & & 1 \\
\hline
\end{tabular}




\begin{tabular}{l|c|c|c}
\hline System Administrator & & 1 & 1 \\
\hline Grand Total & 98 & 84 & 182 \\
\hline
\end{tabular}

Table-4.

Superannuation.

\begin{tabular}{c|c|c|c}
\hline Row Labels & Gross Base Salary & Employee Cont. & Employer Cont. \\
\hline Female & $2,597,924.00$ & $207,833.92$ & $259,792.40$ \\
\hline Male & $3,040,794.33$ & $243,263.55$ & $304,079.43$ \\
\hline Grand Total & $5,638,718.33$ & $451,097.47$ & $563,871.83$ \\
\hline
\end{tabular}

Table-5.

Staff per Location.

\begin{tabular}{c|c|c|c}
\hline Row Labels & Saweni & Suva & Grand Total \\
\hline Female & 84 & 14 & 98 \\
\hline Male & 76 & 8 & 84 \\
\hline Grand Total & 160 & 22 & 182 \\
\hline
\end{tabular}

6.2. Results and Discussions

6.2.1. Fijian women as key providers to sustainable development

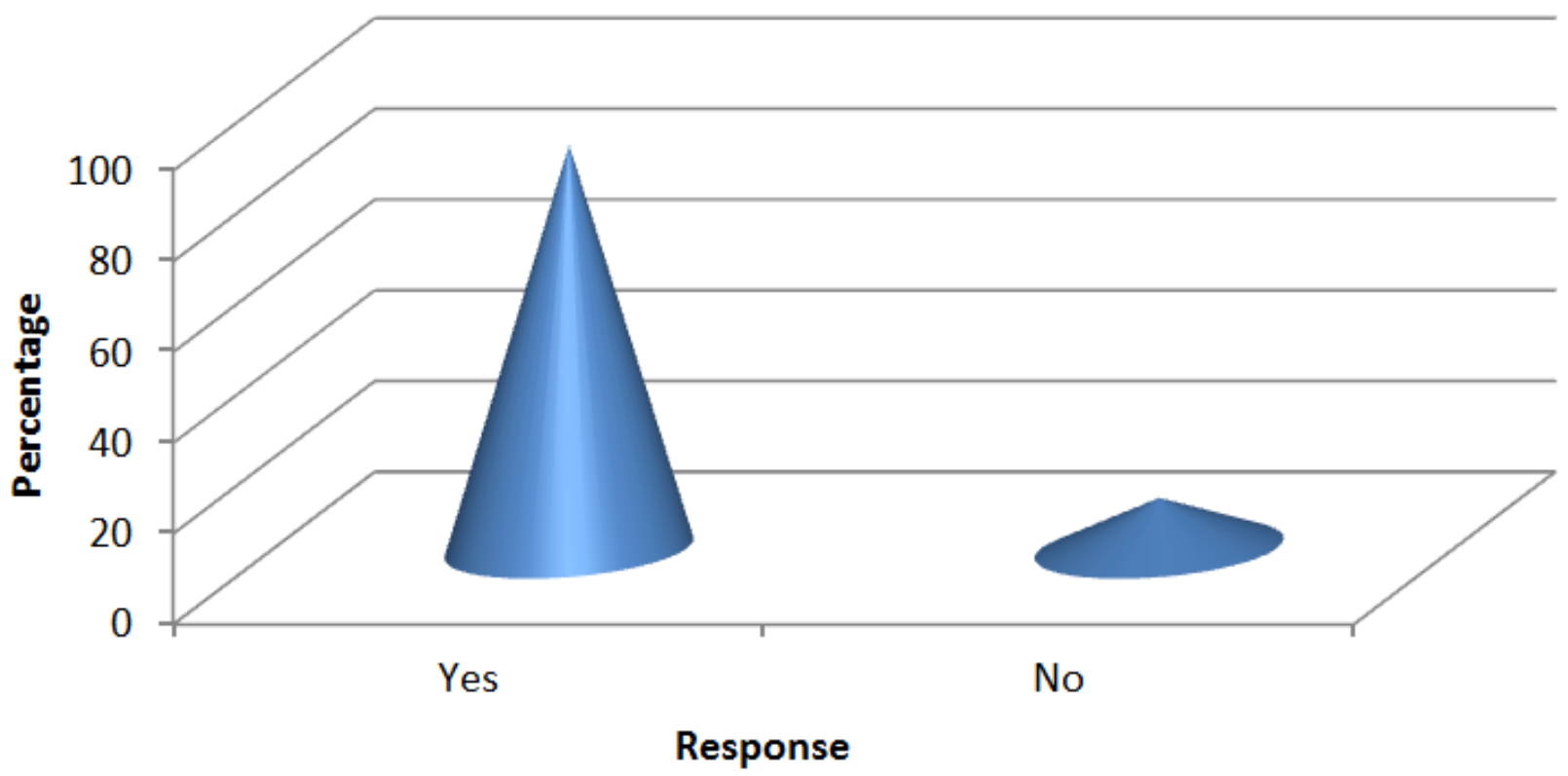

Figure-1.

Are Fijian women as key providers to sustainable development?

$88.9 \%$ of respondents stated that Fijian women are key providers to sustainable development whereas $11.1 \%$ stated that they are not. It was observed that those who agreed that women are key players in sustainable development have largely engaged in aspects of sustainable development such as educating the current generation on the issue, playing myriad roles to encourage SD practices, women empowerment through seminars, workshops, public lectures, professional development sessions to name a few.

In addition to this, the respondents further listed the roles they play at home, community and at work. Most of the female workers at the university play myriad household roles, ranging from being 
caregivers to their children, rearing children, executing chores and heading familial units in terms of fulfilling the needs and wants of the family and others. Other than these responsibilities, a substantial percentage of women are engaged in community work such as key and active participants in religious bodies, school managerial positions and responsibilities, and other community service work that they entail in as and when needed. More so, their professional roles largely require them to be facilitators of the teaching learning process, decision makers, cleaning work, and providers of soft skills and support to list a few.

\subsubsection{Employer's Role}

\section{$\square$ Yes $\square$ No}

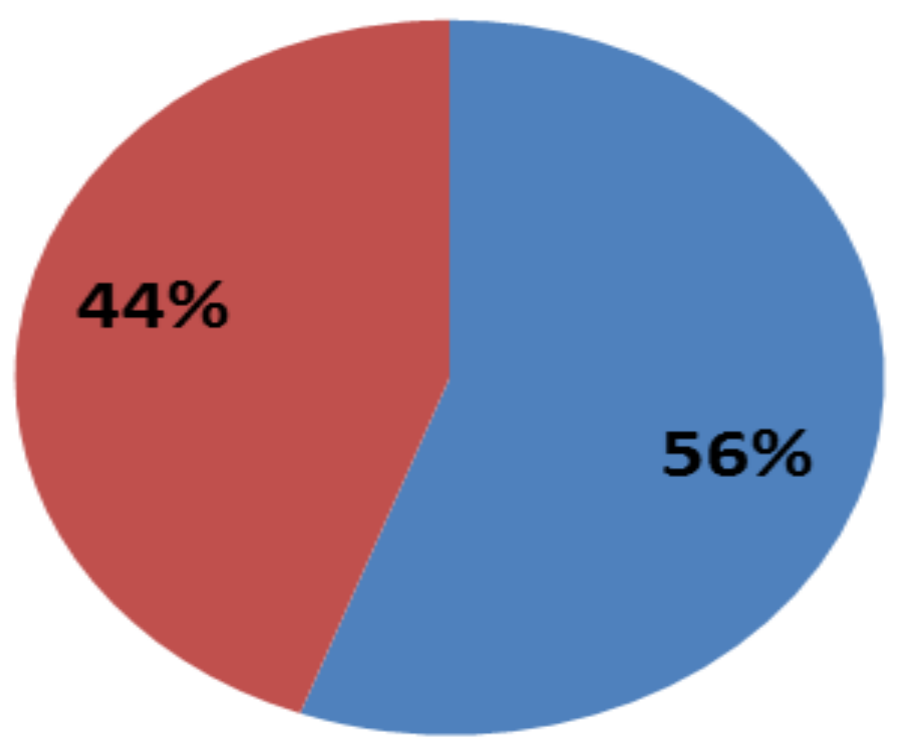

Figure-2.

Are opportunities provided by the employer for sustainable development?

Results from the analysis of the data show that FORTY (40) out of the seventy two respondents $(n=72)$ agreed $(n=40)$ and others disagreed $(n=32)$ to whether employers provide them with opportunities to contribute to their society. The frequency table indicates that 56 percent of the respondents agree that employers provide opportunities but the response is not very positive since a large percentage also disagreed.

A follow-up question requested the respondents to state ways in which they contribute towards sustainable development. Many respondents pointed out that their engagement in community development projects, capacity building initiatives and in decision making processes such as their input in the University Strategic Plan, and representation in various in-house committees enables them to effectively contribute towards the sustainable development of their society and the nation. However, 44 percent participants stated that the organization fell short of addressing gender issues and opportunities to productively empower women in their commitment to SDG's. A few also stressed a need to inculcate gender mainstreaming and gender inclusive practices in key areas and disciplines within the workforce. 


\section{Capacity building $\quad$ Improved healthcare $\quad$ Equal job opportunities $\quad$ Decision making}

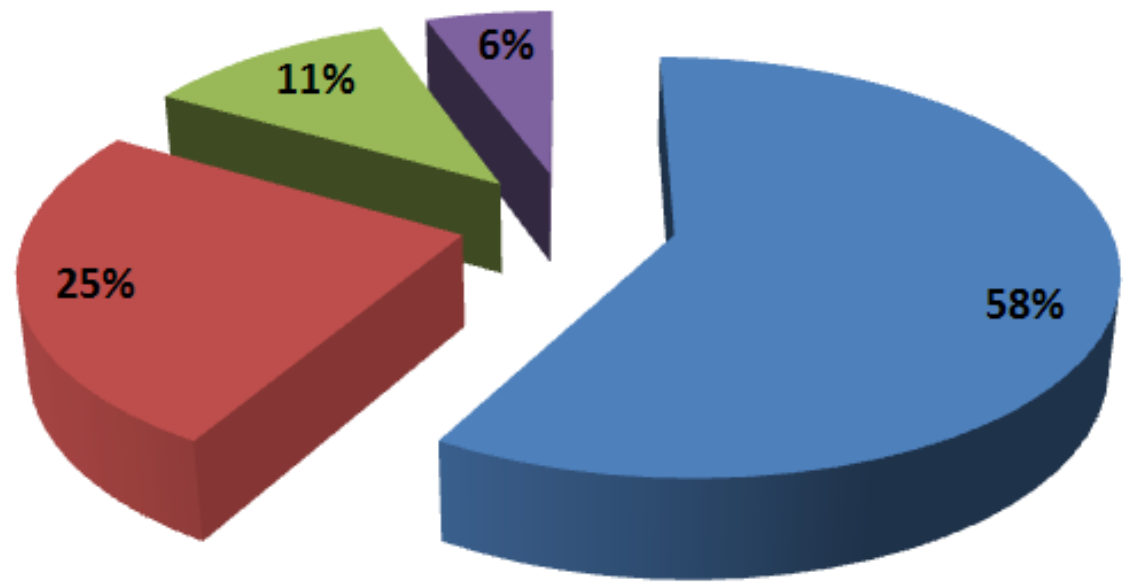

Figure-3.

Opportunities for Suatainable Development.

Results from the analysis of the data show that FORTY (40) out of the seventy two respondents $(n=72)$ said capacity building was one of the opportunities provided by their employer $(n=40)$, while the second best option selected was equal job opportunities $(n=18)$. The result indicates that 58 percent of respondents indicated that capacity building was the best provided opportunity while the second best as per the survey was equal job opportunities which had 25 percent. Other opportunities provided to these female workers are improved healthcare and decision making opportunities. The results depict that it is exigent for the employer to provide a platform for its female human resources to be engaged in major decision making processes other than the current responsibilities designated to female staff in managerial positions. With reference to Table 1.03, the 2017 Staff Positions and Sections explicitly show that female human resources are bottom heavy in their roles and Support Staff are highly gendered in comparison to their counterparts. The staffing positions within the three sections at the university show that though women remain on the sidelines as also indicated by the respondents with an alarming $6 \%$ showing women participation in decision making, women contribute through their risksmart approaches, people skills - soft skills in particular, and leadership strengths that are fundamental to any institution, business and even at governmental levels.

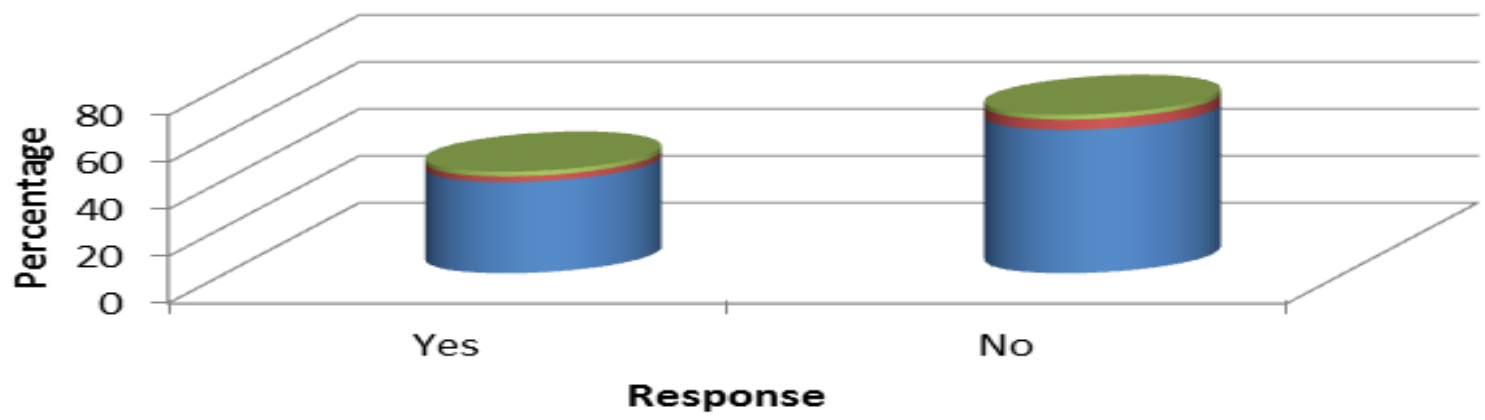

Figure-4.

Gender issues and structural development.

Contemporary Research in Education and English Language Teaching ISSN: 2641-0230

Vol. 2, No. 1, pp. 1-15, 2020

DOI: 10.33094/26410230.2020.21.1.15

(C) 2020 by the authors; licensee Learning Gate 
Results from the analysis of the data show that forty four (44) out of the seventy two respondents $(n=72)$ mentioned that their employer did not include gender issues in the structural development of the institute, whereas the rest $(\mathrm{n}=28)$ stated that gender issues were included. The frequency table indicates that 61.1 percent of the respondents indicated that gender issues are not included in the structural developments. According to literature sighted, gender equality is a crucial element in achieving sustainable development since women are able to take care of the minor issues while men usually deliberate on dominant issues which need to be addressed. This however, is the missing link as pointed out in Table 1.03. Apart from the opportunities provided by the employer as stated in the 2017-2021 Strategic Plan, majority of the respondents feel more can be done to leverage the imbalance in certain areas. It is vital to fathom that we cannot fully maintain gender balance in all areas due to the nature of the work, the demand of the job descriptions. This also heavily relies on peoples individual interests, proficiency in their choice of career selected and trained upon. Also, to maintain sustainable structural change within the tertiary institution, one of the interviewees (2017) suggested the need for the tertiary education provider to commit to and set-up instruments for implementation and reforms in recruitment procedures in research organizations in order to uplift standards and practices for retaining women in research focused organizations primarily aimed at female academics who engage in research.

\subsubsection{Challenges faced by Female Human Resources}

While the female workforce at the institution is presented with opportunities for personal and professional growth, they are also faced with challenges which may hinder their performance at work. A number of participants stated that due to the nature of work and multitasking that majority of them are involved in, they have to juggle with roles and this at times have an impact on their work. Myriad roles also have an impact on their teaching and learning, as some of them are laden with heavy teaching workload. When the teaching workload is more than the required normal load, coupled with additional responsibilities do have an impact on the staff. This is not necessarily the case across academia, however, many respondents pointed out that working outside the normal teaching load has a direct impact on their ability to successfully execute other work such as completion of research in a given timeframe.

Other than this, majority of the respondents stressed that they are mostly playing a crucial role in many in-house activities organized by the institution. This requires additional hours in terms of preparations, logistical arrangements and overseeing the successful implementation of the events. Having to systematize scores of undertakings impede some women workforce to effectively perform other tasks. A few of the respondents stated that there are times when they are given extra responsibilities without prior discussion and this puts additional pressure on them. Also, some respondents mentioned the need to have a bottom-up approach, in other words the democratic leadership style that entails the viewpoints and suggestions of junior staff in the workforce. Since the senior positions are largely male dominated, some respondents feel lack of female participation and representation in decision making.

Added to that, one of the interviewees mentioned that at times the workplace lacked emotional intelligence when dealing with human resources. This was evident in situations where personnels in key positions lacked emotional intelligence given the circumstance a particular female staff may have been. Another interviewee (2017) emphasised that "for any institution to grow it needs people and as the common saying goes that it is the people who makes the workplace." Besides, the research noted that women have a dissimilar career trajectory than men, thus they require flexible hours and schedules to accommodate the heavy demands on their time, and should this provision be made available at the workplace. One of the interviewees stated that: "The institution fails to provide adequate childcare support or facilities for working women who are mothers as well." The respondents further highlighted that: "for women who work and have children, appropriate and affordable childcare options need to be in place." However, this support is missing at the institution where out of the 182 staff, 98 are female, making up a $53.8 \%$ of women in the workforce at the university. 


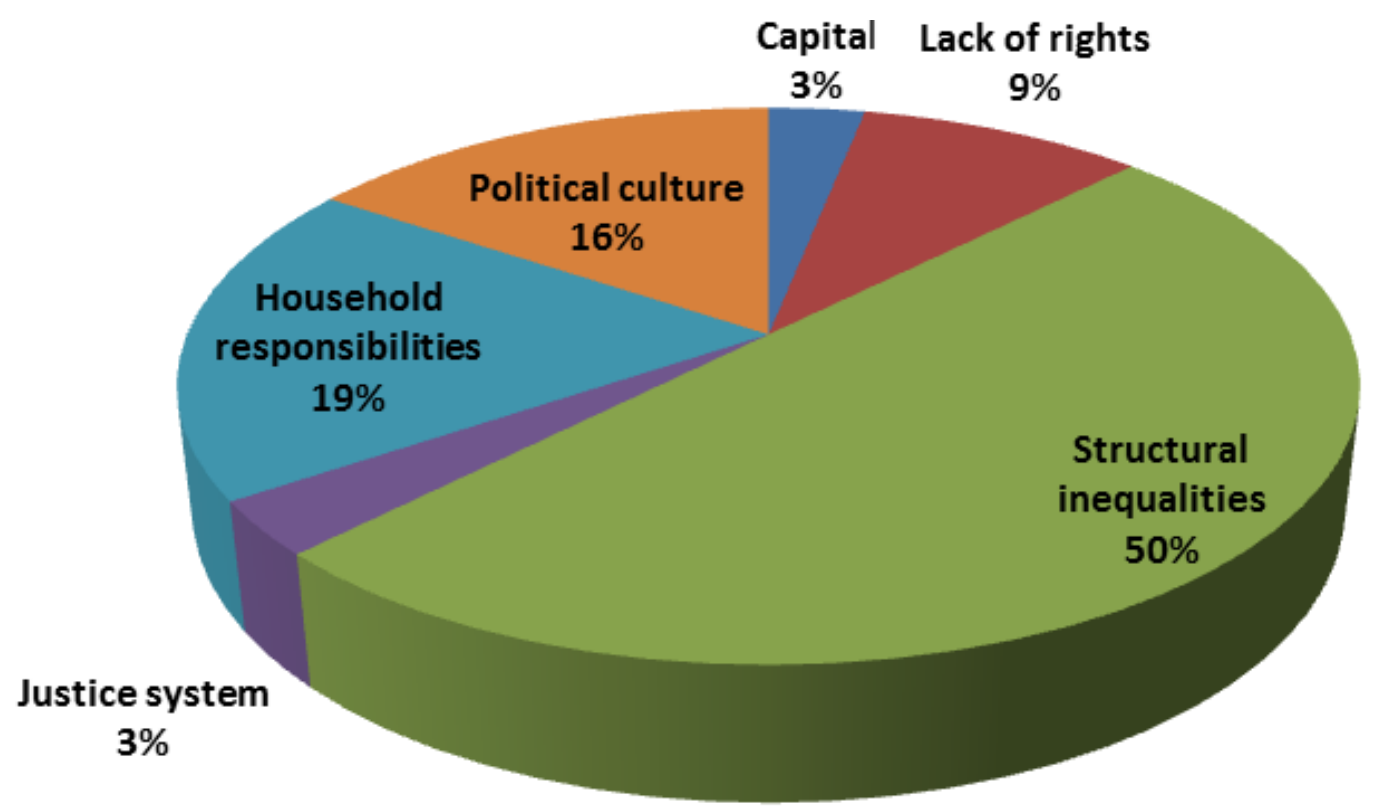

Figure-5.

Factors limiting personal growth.

Results from the analysis of the data show that thirty two $(n=32)$ out of the seventy two respondents $(\mathrm{n}=72)$ said that structural inequalities is the major limitation to their growth. The second limiting factor considered was household responsibilities $(n=12)$. Structural inequalities would be where the employer or the authorities of the nation are not gender inclusive when designing policies, thus affecting certain groups of people. Many households still consider household chores to be women's responsibilities, thus women are tasked to take care of almost everything at home. This may limit their growth since they may not have enough time available for personal nourishment and development. The political culture of a nation/country can also be a hindrance to anyone's growth, thus, it is important that governments and other authorities consider the roles played by both the gender and reflect gender equality in every decision they take. Moreover, lack of rights is another factor limiting personal growth. Despite having rights in place for every individual, there are families which still limit individual rights and mobility. Suppressions of such nature can be disastrous to one's growth. Finally, lack of capital is another contributing factor.

\section{Recommendations}

There is no denial of women's contribution towards economic, social, environment and infrastructure developments of Fijian society. The same is resonated in the different domains that women work comprising the paid labour force. Thus, the research findings illustrate a need for the tertiary education provider, in this case The University of Fiji to apply a participatory approach in all its dealings ranging from teaching and learning, serving senior positions, recruitments, structural change, appointments to research for exchanging knowledge and experience and learning from others. With a participatory approach, all the human resources in the workforce will be able to draw on the knowledge shared by each other, and the issue of gender equality will be fully addressed.

More so, there is a need for the employer, in this case the education provider to make available the structural balance within the university in all areas ranging from recruitments, appointments, fringe benefits, capacity building opportunities and promotions so that female workforce are empowered to 
continue to work at the university and feel their roles are crucial Also, with the staffing positions depicting that roles and positions are by far gendered, there is a need for the university to ensure that schemes are developed in order to recruit women for non-traditional jobs such as Information Technology, Managerial Positions and Executive Positions so that women are engaged in productive decision making processes, assuredly for a sustainable development of the country.

It is apparent that the institution needs to invest in assisting women achieve more work/life balance by providing childcare facilities or support for working mothers. This will address both the growing economic droop and skewed demographics.

\section{Conclusion}

The research findings depict the roles Fijian women play in their various capacities to contribute in the fields of economic and social development of Fijian society through paid employment services in the various sectors of the economy. With Fiji's commitment to Sustainable Development Goals (SDG), the research concludes that women's contributions are fundamental in achieving sustainability and overall growth of the country. With a fairly balanced women representation in the workforce at The University of Fiji, the findings also illustrates gaps in terms of gender equality, structural inequalities at the university, capital variations across the globe, to name a few that obstruct women's potential to fully contribute towards their personal as well as professional growth. However, the findings suggest that it is essential than ever to espouse the growth of Fijian women through education, capacity building, improved healthcare, equal job opportunities and women participation and representation at national levels for decision making processes. Hence, this paper has investigated the various roles played by women workforce at The University of Fiji and their contributions towards sustainable development of women. The paper has suggested conceivable resolutions to equip Fijian women workforce at the University of Fiji in order to effectively contribute towards the sustainable development and growth of Fiji.

\section{References}

Asian Development Bank. (2014). Country partnership strategy. Fiji: Asian Development Bank.

Boston University. (2010). Sustainable development insights. Boston: Boston University.

European Parliament. (2016a). Directorate general for internal policies, policy department C: Citizens' rights and constitutional affairs, women's right and gender equality, women's empowerment and its links to sustainable development. Retrieved from: http://www.rosavzw.be/digidocs/ddo01477_2016_Empowerment_links_sustainable_development_EP.pdf. [Accessed 2 March 2017].

European Parliament. (2016b). Women's empowerment and its links to sustainable development in-depth analysis. Brussels: Policy Department for Citizen's Rights and Constitutional Affairs.

Hooper, A. (2005). Culture and sustainable development in the pacific. Canberra: ANU E Press \& Asia Pacific Press.

Kaushik, L. (2016). Women and sustainable development. Canadian Woman Studies, 31(1,2), 103-105.

Koshy, K., Mataki, M., \& Lal, M. (2008). Sustainable development - a pacific islands perspective. Samoa: UNESCO Cluster Office for the Pacific States.

Ogato, G. S. (2013). The quest for gender equality and women's empowerment in least developed countries: Policy and strategy implications for achieving millennium development goals in Ethiopia. International Journal of Sociology and Anthropology, 5(9), 358-372.

Organization for Economic Co-operation and Development (OECD). (2008). 2008 annual report on sustainable development work in the OECD. Organization for Economic Co-operation and Development.

Skanavis, C., \& Sakellari, M. (2008). Gender and sustainable tourism: Women's participation in the environmental decisionmaking process. European Journal of Tourism Research, 1(2), 78-93.

UN Women. (2015). Progress of the world's women 2015-2016: Transforming economies, realizing rights, United Nations entity for gender equality and the empowerment of women. Retrieved from: http://progress.unwomen.org/en/2015/pdf/UNW_progressreport.pdf. [Accessed 2 March 2017].

UN Women. (2016). Women and sustainable development goals. Nairobi: UN Women Eastern and Southern Africa Regional Office.

UN Women Publications. (2013). Economic empowerment of women: Facts and Figures: Economic Empowerment. Retrieved from: http://www.unwomen.org/en/what-we-do/economic-empowerment/facts-and-figures. [Accessed 2 March $2017]$. 
World Health Organization. (2017). Millennium development goals (MDGs). Retrieved from: http://www.who.int/topics/millennium_development_goals/en/. [Accessed 1 March 2017].

Zibiah, A. (2015). Be engaged for progress. The Fiji Times, 27 June. Retrieved from http://fijitimes.com/story.aspx?ref=archive\&id=311399. [Accessed on 6th April 2017]. 